\title{
First record of microplastics in stomach content of the southern king crab Lithodes santolla (Anomura: Lithodidae), Nassau bay, Cape Horn, Chile
}

\author{
Primer registro de microplásticos en contenido estomacal \\ de centolla Lithodes santolla (Anomura: Lithodidae), \\ bahía Nassau, Cabo de Hornos, Chile \\ Claudia Andrade ${ }^{1} \&$ Fernanda Ovando ${ }^{1}$
}

\begin{abstract}
This study reports the first record of microplastics in the stomach contents of the king crab Lithodes santolla. Samples were collected in Nassau Bay during September 2017. Plastics ingested belonged to small microplastics between 3.0 and more than $20 \mathrm{~mm}$ long having mainly blue color. Their frequency of occurrence in stomachs was $27 \%$. The microplastic ingestion by L. santolla may present not only a risk for the species self, also for other trophic levels in the food web.
\end{abstract}

\section{Key Words:}

plastic fibers, crustacean, ingestion, marine pollution, Subantarctic.

\section{Resumen}

El presente estudio reporta por primera vez la presencia de microplásticos en los estómagos del crustáceo comercial centolla Lithodes santolla. Las muestras fueron colectadas en septiembre de 2017, en el sector de bahía Nassau, en el archipiélago de Cabo de Hornos, Chile. Los plásticos ingeridos corresponden a pequeñas fibras microplásticas entre 3 y más de $20 \mathrm{~mm}$ de longitud, los cuales tienen una coloración principalmente azul. Su frecuencia de ocurrencia en los estómagos fue de un $27 \%$. La ingestión de microplásticos podría representar un riesgo para la especie como también para otros organismos predadores de L. santolla y así afectando a toda la trama trófica marina.

\section{Palabras Clave:}

fibras plásticas, crustacea, ingestión, contaminación plástica, Subantártica.

\section{INTRODUCTION}

Plastic debris have become a global problem in all marine ecosystems since it is widespread in the water column and seabed. In fact, plastic debris may have adverse ecological impacts on marine biota as in the bio-magnification when enter marine food web (Thompson et al. 2004; Teuten et al. 2007; Barnes et al. 2009; Andrady, 2011). Therefore, significant concern exists due increasing of micro-, meso- and macro- plastic marine litter (Hidalgo-Ruz et al. 2012), which comprise many products of degradation of larger plastic debris into smaller fragments, or originate from synthetic fabrics clothing such as fibers (Thompson et al. 2004; Andrady, 2011; Cole et al. 2011). In this sense, several definitions are used to define plastic pollution, but the most commonly used is that microplastics are plastic particles smaller than $5 \mathrm{~mm}$ diameter (Arthur et al. 2009); such as fibers of polyester, nylon, polyethylene, polypropylene and their persistence in the marine environment take long periods of time to degrade (Hopewell et al. 2009). For instance, several marine organisms may ingest accidentally these microplastics in the natural environment which can cause internal damage due ingestion,

\footnotetext{
1 Instituto de la Patagonia, Universidad de Magallanes,

Punta Arenas, Chile.

$\square$ claudia.andrade@umag.cl
} 


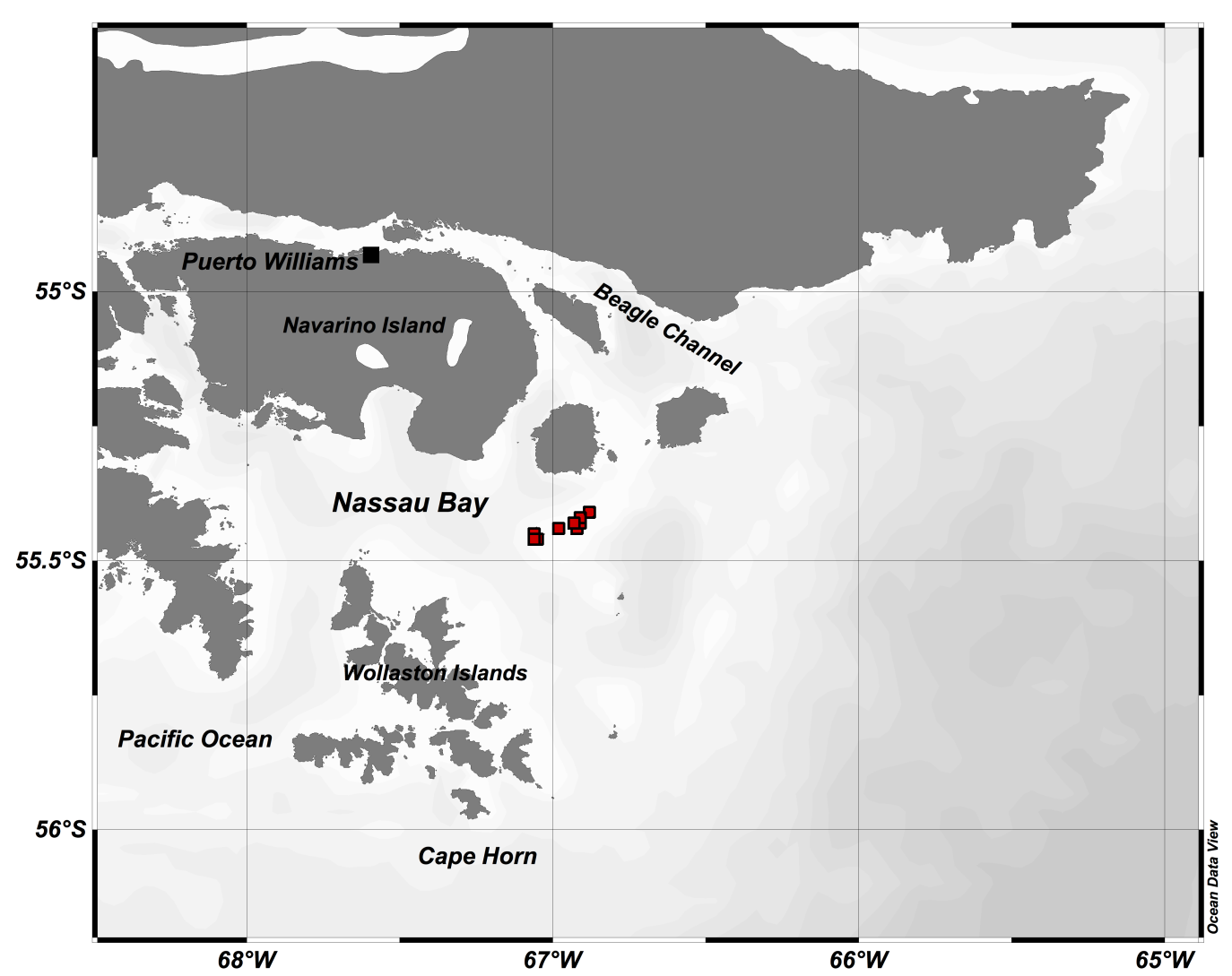

Fig. 1. Location map of study area showing sites of collecting Lithodes santolla samples.

poisoning due harmful chemicals, reducing their fitness and increasing mortality, entanglement, among other effects (e.g., Anderson et al. 2016; Vermaire et al. 2017).

Despite the economic and ecological importance of the southern king crab Lithodes santolla (Molina, 1782) as the most important decapod crab for fishery in Chilean/Argentinian Patagonia (Lovrich, 1997; Vinuesa et al. 2013), investigation of potential plastic ingestion and their negative impacts on marine biota in the Subantarctic Magellan region is unknown.

In this context, the aim of this study was provide empirical evidence of microplastic occurrence in the stomach content of Lithodes santolla.

\section{MATERIAL AND METHODS}

\section{Sample collection}

Thirty specimens of the southern king crab
Lithodes santolla were collected in September 2017 by trap gears in Nassau Bay $\left(5^{\circ} 41.67^{\prime} \mathrm{S}\right.$; $\left.67^{\circ} 66.67^{\prime} \mathrm{W}\right)$, south of Navarino Island and north of Chile Cape Horn (Fig. 1). The traps were disposed randomly between 40 and 60 meters water depth with bait inside.

\section{Work at sea}

The carapace length and width $(\mathrm{mm})$ were registered and crabs were classified as the sexes of the individuals were determined by external morphological following Stevens \& Jewett (2014) and Lovrich and Vinuesa (2016). The wet weight was recorded to the nearest $0.01 \mathrm{~g}$ of each specimen. Then, stomach of each specimen were extracted and fixed in a $10 \%$ formaldehyde-sea water solution.

\section{Laboratory work}

The stomach samples were transported to the 


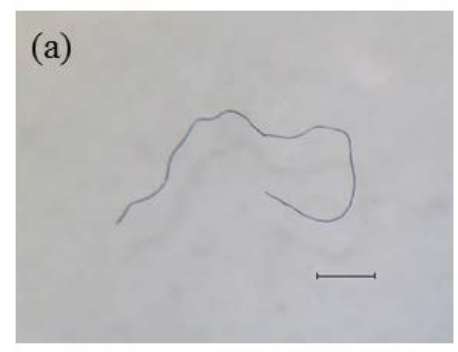

(b)

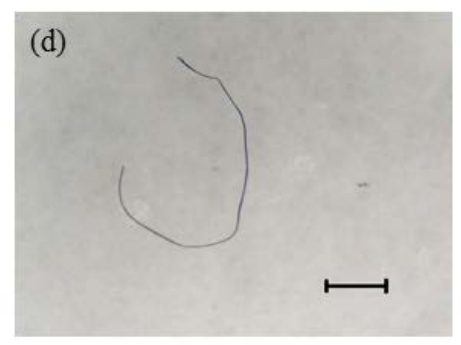

(g)

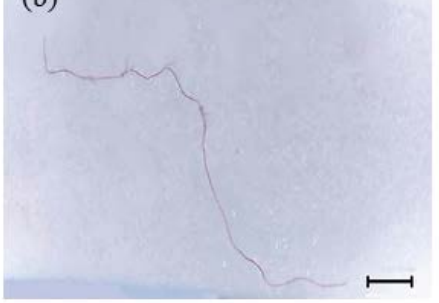

(e)

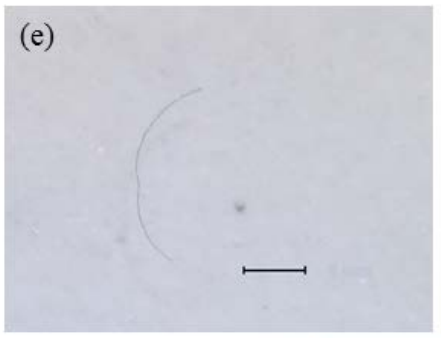

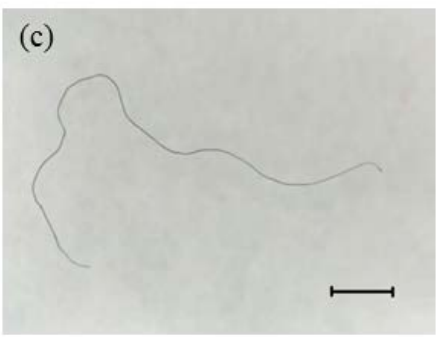

(f)

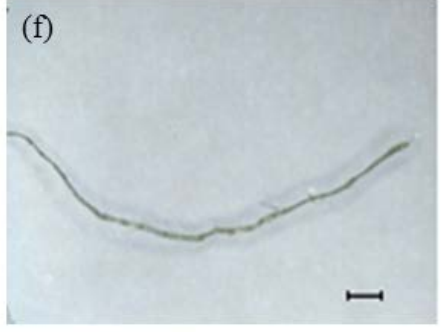

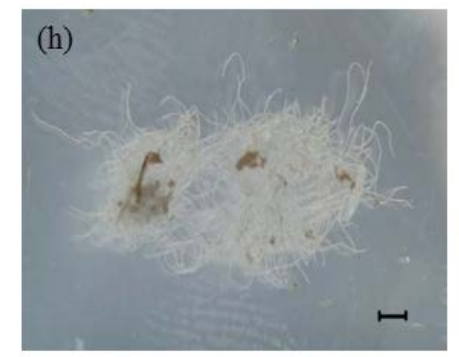

Fig. 2. Images of plastic fibers found in the stomach content of the southern King crab Lithodes santolla, where (a) correspond to the specimen $\mathrm{N}^{\circ} 1$, (b) specimen $\mathrm{N}^{\circ} 3$, (c), (d) and (e) specimen $\mathrm{N}^{\circ} 11$, (f) specimen $\mathrm{N}^{\circ} 19$, (g) specimen $\mathrm{N}^{\circ} 24$ and (h) specimen $\mathrm{N}^{\circ} 27$. Scale bar $=1 \mathrm{~mm}$.

laboratory (Instituto de la Patagonia; University de Magallanes). In laboratory, all the stomach contents were examined under stereoscopic microscope. The microplastic fragments were sorting from the remaining biological stomach content. The characteristic of the microplastic fragments were determined according to the color, amount and size for each observation. The biological stomach content will be report separately in other publication.

\section{RESULTS}

Based on gut content analysis, $27 \%$ of individuals ( 8 specimens) had ingested between 1 and 3 pieces of microplastic (see Table 1), with the majority being fibers, which are a subcategory of microplastics. The range of lengths was 3 (specimen $\mathrm{N}^{\circ} 11$ ) to more then $20 \mathrm{~mm}$ (specimen $\mathrm{N}^{\circ} 27$ ); however, in the specimen $\mathrm{N}^{\circ} 27$ the length of the fiber may be underestimated due to the particular difficulty of disentangling the mass of fiber (Fig. 2). Most of the fibers were detected in male individuals than females but with similar carapace size measurements (see Table 1).

Shape of plastics varied from short to elongated fiber, or even a mass of fiber (Fig. 2). In addition, differences in colors of plastic fibers were observed (Fig. 3), in which blue colors seem to be dominant in males but not for females, where red and transparent fibers were dominant.

\section{DISCUSION AND CONCLUSIONS}

Our current observations clearly show the southern king crab Lithodes santolla is ingesting microplastics in their natural environment and thus demonstrates that plastics has already entered magellanic marine waters. This is surprisingly, due 

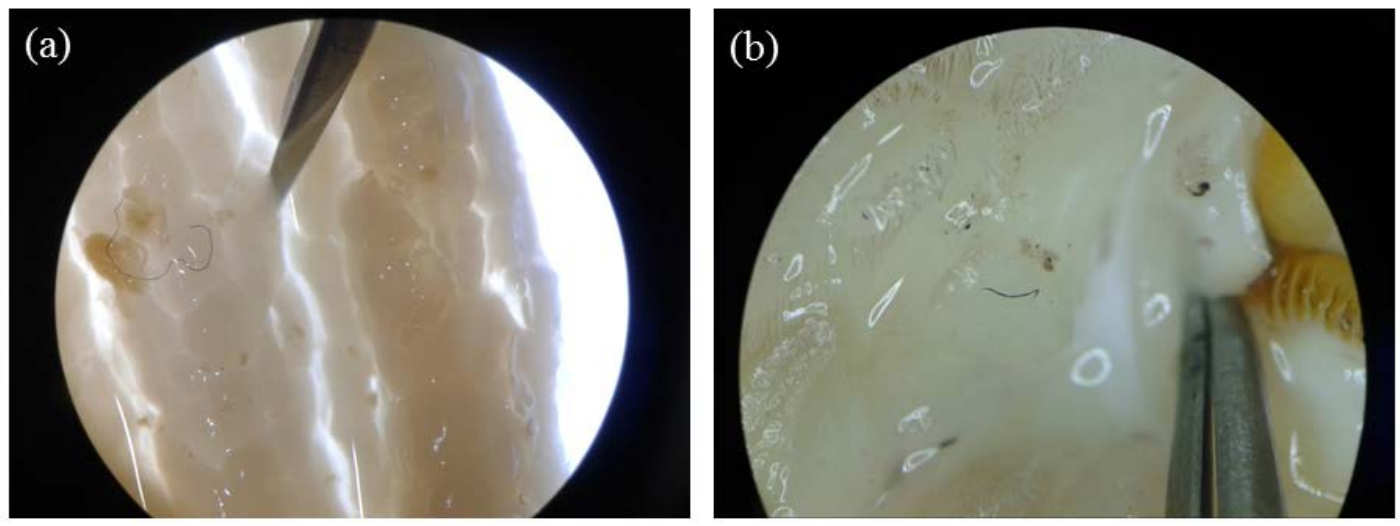

Fig. 3. Closer inspection of the revealed presence of plastic fibers in the gut content of Lithodes santolla, (a) specimen $\mathrm{N}^{\circ} 6$ and (b) specimen $\mathrm{N}^{\circ} 10$.

that Nassau Bay is a remote area, inside a one of the pristine regions in the world with the lowest human population densities in Chile $(<5$ people / $\mathrm{km}^{2}$; Mittermeier et al. 2002).

The probable origin and transport of plastic waste to the sampling area could be from fishery activities (e.g., waste of fishermen such as ropes or net repairing), and by floating marine debris (Hinojosa \& Thiel 2009). An alternative mechanism to transport of the plastic debris may be by means ocean currents too (Barnes et al. 2009). At Nassau Bay, it seems that fishing gears disposal on the seabed (i.e., fisheries traps) led to the origin of plastic pollution. Thus is very likely a reflection of the microfibers found on stomach contents of $L$. santolla. Herein we distinguished microplastics fibers with different colors and sizes. Such kind of materials have a wide range of domestic and industrial uses from fishery ropes to synthetic clothing (Thompson et al. 2004). Therefore, more accuracy chemical analysis is need for determining the origin of the microplastics fibers on stomach content of $L$. santolla.

Possible plastic ingestion pathways of the king crab may be by indirect or direct consumption, alternatively by trophic transfer from lower trophic level in the food chain (Anderson et al. 2016). L. santolla is generalist decapod, with an opportunistic feeding strategy and it has a varied diet, including gastropods, crustaceans, among others (Lovrich, 2014; Lovrich \& Vinuesa, 2016). However, this is the first record of plastic fibers as a new item on stomach content of $L$. santolla and further studies are needed to predict potential health risk (e.g., diseases, lethal starvation). Similar results of the plastic contamination in Nephrops norvegicus (decapods crustacean) has showed that the filaments are unable to pass through the gastric mill system and the filament are unable to be excrete (Murray \& Cowie, 2011). A wide range of the effects of plastic fibers inside of the invertebrate's stomach content caused lower feeding rate and reduced energy reserves (see. Taylor et al. 2016).

L. santolla is an important food source for local fisheries but also for other predators in the natural environment. Few registers indicated that juveniles of $L$. santolla are predated by starfish Cosmasteria lurida, the flightless steamer duck Tachyeres pteneres, the sea gull Larus dominicanus (Campodónico et al. 1983) and by the marine otter Lutra felina (Sielfeld, 1990). However, predator records on L. santolla adults are rare (Lovrich, 2014). Their likely large size, hardness of exoskeleton and presence of thorns are probably against predators (Lovrich, op. cit.). L. santolla trophic interactions are not yet totally established, however the present study suggest that ingestion of microplastic by L. santolla might have implications for the rest of the food web.

Worldwide, there are few studies about the negative impact of microplastic on marine biota and food webs (e.g., Derraik, 2002; Murray \& Cowie, 2011). Ingestion of plastic fibers may cause physical harm and effects on energy metabolism (Anderson et al. 2016). However, we need further investigation to ascertain their potential hazard associated to the plastic debris ingestion for this specie, and on the impacts of plastic transfer throughout the trophic web. 
Table 1. Shows specimen collected, carapace size (length and width; mm), weight (grs), sex, presence or absence, colour, size of microplastic fibers found in the stomach contents of Lithodes santolla.

\begin{tabular}{|c|c|c|c|c|c|c|c|c|c|c|}
\hline \multirow[t]{2}{*}{ Specimen } & \multirow{2}{*}{$\begin{array}{c}\text { Carapace } \\
\text { lenght }(\mathrm{mm})\end{array}$} & \multirow{2}{*}{$\begin{array}{c}\text { Carapace } \\
\text { width (mm) }\end{array}$} & \multirow[t]{2}{*}{ Weight (grs) } & \multirow[t]{2}{*}{ Sex } & \multirow{2}{*}{$\begin{array}{c}\text { Presence/absence } \\
\text { plastic }\end{array}$} & \multirow{2}{*}{$\begin{array}{l}\text { Plastic } \\
\text { color }\end{array}$} & \multirow{2}{*}{$\begin{array}{c}\text { Plastic } \\
\text { long (mm) }\end{array}$} & \multirow[t]{2}{*}{ Photo } & \multicolumn{2}{|c|}{ Location } \\
\hline & & & & & & & & & $\mathrm{S}^{\circ}$ & $\mathrm{W}^{\circ}$ \\
\hline 1 & 118 & 131 & 1200 & Male & Yes & blue & 8.5 & (a) & 55.42 & 66.91 \\
\hline 2 & 115 & 119 & 1100 & Male & No & - & - & - & 55.43 & 66.91 \\
\hline 3 & 117 & 123 & 1200 & Male & Yes & red & 8.0 & (b) & 55.43 & 66.91 \\
\hline 4 & 116 & 124 & 1200 & Male & No & - & - & - & 55.41 & 66.88 \\
\hline 5 & 114 & 124 & 1100 & Male & No & - & - & - & 55.44 & 66.92 \\
\hline 6 & 115 & 124 & 1100 & Male & Yes & blue & 9 & - & 55.41 & 66.88 \\
\hline 7 & 109 & 119 & 1100 & Male & No & - & - & - & 55.43 & 66.91 \\
\hline 8 & 104 & 108 & 1000 & Male & No & - & - & - & 55.41 & 66.88 \\
\hline 9 & 119 & 125 & 1300 & Male & No & - & - & - & 55.43 & 66.91 \\
\hline 10 & 101 & 114 & 1000 & Male & Yes & blue & 3 & - & 55.43 & 66.91 \\
\hline 11 & 117 & 124 & 1300 & Male & Yes & blue & $10 / 6.5 / 3$ & (c). (d) and (e) & 55.43 & 66.91 \\
\hline 12 & 117 & 121 & 1200 & Male & No & - & - & - & 55.41 & 66.88 \\
\hline 13 & 108 & 114 & 800 & Male & No & - & - & - & 55.41 & 66.88 \\
\hline 14 & 108 & 112 & 800 & Male & No & - & - & - & 55.41 & 66.88 \\
\hline 15 & 88 & 90 & 700 & Male & No & - & - & - & 55.42 & 66.91 \\
\hline 16 & 132 & 133 & 2000 & Female & No & - & - & - & 55.46 & 67.06 \\
\hline 17 & 120 & 127 & 1200 & Female & No & - & - & - & 55.46 & 67.06 \\
\hline 18 & 120 & 125 & 1200 & Female & No & - & - & - & 55.46 & 67.06 \\
\hline 19 & 98 & 99 & 800 & Female & Yes & blue & 14.0 & (f) & 55.46 & 67.06 \\
\hline 20 & 121 & 125 & 1400 & Female & No & - & - & - & 55.45 & 67.06 \\
\hline 21 & 107 & 106 & 700 & Female & No & - & - & - & 55.45 & 67.06 \\
\hline 22 & 112 & 117 & 1000 & Female & No & - & - & - & 55.46 & 67.06 \\
\hline 23 & 105 & 107 & 800 & Female & No & - & - & - & 55.46 & 67.05 \\
\hline 24 & 109 & 106 & 1000 & Female & Yes & red & 23.1 & (g) & 55.43 & 66.93 \\
\hline 25 & 112 & 119 & 1000 & Female & No & - & - & - & 55.44 & 66.98 \\
\hline 26 & 98 & 102 & 700 & Female & No & - & - & - & 55.46 & 67.06 \\
\hline 27 & 98 & 99 & 600 & Female & Yes & transparent & more than 30 & (h) & 55.46 & 67.06 \\
\hline 28 & 96 & 99 & 600 & Female & No & - & - & - & 55.44 & 66.98 \\
\hline 29 & 96 & 98 & 600 & Female & No & - & - & - & 55.44 & 66.98 \\
\hline 30 & 97 & 100 & 600 & Female & No & - & - & - & 55.44 & 66.98 \\
\hline
\end{tabular}

\section{ACKNOWLEDGMENTS}

This work was financed by the Instituto de Fomento Pesquero (IFOP) under the project "Programa de Seguimiento de las principales Pesquerías Nacionales, año 2017. Pesquerías de Crustáceos 2017/2018", with the specific study "Dieta y rol trófico de la centolla Lithodes santolla" conducted by Dr. Claudia Andrade at the University of Magallanes, Chile. We would like to thank all scientific and technical staff from IFOP for their valuable assistance and coordination of the field work campaigns. A special thank to the Chief of IFOP Magallanes, Biol. Erik Daza for his constantly support in the development of the project and Alex Oyarzo to collect the king crab 
specimens. We would like to thank the reviewers for their thoughtful recommendation of the manuscript.

\section{REFERENCES}

Anderson, J. C., Park, B. J., \& Palace, V. P. (2016). Microplastics in aquatic environments: Implications for Canadian ecosystems. Environmental Pollution, 218, 269-280.

Andrady, A. L. (2011). Microplastics in the marine environment. Marine Pollution Bulletin, 62(8), 1596-1605.

Arthur, C., Baker, J. E., \& Bamford, H. A. (2009). Proceedings of the International Research Workshop on the Occurrence, Effects, and Fate of Microplastic Marine Debris, September 9-11, 2008, University of Washington Tacoma, Tacoma, WA, USA.

Barnes, D. K., Galgani, F., Thompson, R. C., \& Barlaz, M. (2009). Accumulation and fragmentation of plastic debris in global environments. Philosophical Transactions of the Royal Society of London B: Biological Sciences, 364(1526), 19851998.

Campódonico, I., Hernández, M. B., \& Riveros, E. (1983). Investigación, manejo y control de las pesquerías de Centolla y Centollón de la XII Región. Informe consolidado: recurso centollón. Informes Instituto de la Patagonia, 25, 1-97.

Cole, M., Lindeque, P., Halsband, C., \& Galloway, T. S. (2011). Microplastics as contaminants in the marine environment: a review. Marine Pollution Bulletin, 62(12), 2588-2597.

Derraik, J. G. (2002). The pollution of the marine environment by plastic debris: a review. Marine Pollution Bulletin, 44(9), 842-852.

Hidalgo-Ruz, V., Gutow, L., Thompson, R. C., \& Thiel, M. (2012). Microplastics in the marine environment: a review of the methods used for identification and quantification. Environmental Science \& Technology, 46(6), 3060-3075.

Hinojosa, I. A., \& Thiel, M. (2009). Floating marine debris in fjords, gulfs and channels of southern Chile. Marine Pollution Bulletin, 58(3), 341-350.
Hopewell, J., Dvorak, R., \& Kosior, E. (2009). Plastics recycling: challenges and opportunities. Philosophical Transactions of the Royal Society of London B: Biological Sciences, 364(1526), 21152126.

Lovrich, G. A. (1997). La pesquería mixta de las centollas Lithodes santolla y Paralomis granulosa (Anomura: Lithodidae) en Tierra del Fuego, Argentina. Investigaciones Marinas, 25, 41-57.

Lovrich, G. A. (2014). Lithodidae. En J. A. Calcagno (Ed.), Invertebrados del Mar Argentino (pp. 241-261). Vazquez Mazzini Editores.

Lovrich, G. A., \& Vinuesa, J. H. (2016). Biología de las centollas (Anomura: Lithodidae). En E. Boschi (Ed.), El mar Argentino y sus recursos pesqueros (pp. 183-212).

Mittermeier, R. A, Mittermeier, C., Robles-Gil, P., Pilgrim, J., Fonseca, G., Brook, T., \& Konstant, W. (2002). Wilderness: Earth's last wild places. CEMEX-Conservation International, Washington, D.C., USA.

Murray, F., \& Cowie, P. R. (2011). Plastic contamination in the decapod crustacean Nephrops norvegicus (Linnaeus, 1758). Marine Pollution Bulletin, 62(6), 1207-1217.

Sielfeld, W. K. (1990). Dieta del chungungo (Lutra feline (Molina, 1782)) (Mustelidae, Carnivora) en Chile Austral. Revista de Investigaciones Científicas y Tecnológicas, Serie Ciencias del Mar, 1, 23-29.

Stevens, B. G., \& Jewett, S. C. (2014). Growth, molting, and feeding of king crabs. In Bradley G. Stevens (Ed.), King crabs of the world: Biology and fisheries management (pp. 315-361). CRC Press, Taylor and Francis Group.

Vermaire, J. C., Pomeroy, C., Herczegh, S. M., Haggart, O., \& Murphy, M. (2017). Microplastic abundance and distribution in the open water and sediment of the Ottawa River, Canada, and its tributaries. FACETS, 2(1), 301-314.

Vinuesa, J. H., Varisco, M. A., \& Balzi, P. (2013). Feeding strategy of early juvenile stages of the southern king crab Lithodes santolla in the San Jorge Gulf, Argentina. Revista 
de Biología Marina y Oceanografía, 48(2), 353-363.

Taylor, M. L., Gwinnett, C., Robinson, L. F., \& Woodall, L. C. (2016). Plastic microfibre ingestion by deep-sea organisms. Scientific reports, 6.

Teuten, E. L., Rowland, S. J., Galloway, T. S., \& Thompson, R. C. (2007). Potential for plastics to transport hydrophobic contaminants. Environmental Science \& Technology, 41(22), 7759-7764.

Thompson, R. C., Olsen, Y., Mitchell, R. P., Davis, A., Rowland, S. J., John, A. W., McGonigle, D., \& Russell, A. E. (2004). Lost at sea: where is all the plastic?. Science, 304(5672), 838-838. 
